\section{Review Article}

\section{Check for updates}

\section{OPEN ACCESS}

Received: Oct 12, 2019

Revised: Feb 17, 2020

Accepted: Mar 5, 2020

Moraes IQS, Nascimento TG, Silva AT, Lira

LMSS, Parolia A, Porto ICCM

*Correspondence to

Isabel Cristina Celerino de Moraes Porto, MSc, PhD

Associate Professor, Department of Restorative Dentistry, School of Dentistry, Federal University of Alagoas, Campus A. C. Simões, Av. Lourival Melo Mota, S/N, Tabuleiro do Martins, Maceió, Alagoas 57072-970, Brazil. E-mail: isabel.porto@foufal.ufal.br

Copyright (c) 2020. The Korean Academy of Conservative Dentistry

This is an Open Access article distributed under the terms of the Creative Commons Attribution Non-Commercial License (https:// creativecommons.org/licenses/by-nc/4.0/) which permits unrestricted non-commercial use, distribution, and reproduction in any medium, provided the original work is properly cited.

\section{Funding}

The authors are grateful to the Foundation for Research Support of the State of Alagoas (Fundação de Apoio à Pesquisa do Estado de Alagoas [FAPEAL]) for financial support.

Conflict of Interest

No potential conflict of interest relevant to this article was reported.

\title{
Inhibition of matrix metalloproteinases: a troubleshooting for dentin adhesion
}

\author{
Izadora Quintela Souza de Moraes (1),' Ticiano Gomes do Nascimento $\mathbb{1}$,' \\ Antonio Thomás da Silva $\mathbb{D}^{1},{ }^{1}$ Lilian Maria Santos Silva de Lira $\mathbb{D}^{\mathbb{D},}{ }^{1}$ \\ Abhishek Parolia $\mathbb{D}^{2},{ }^{2}$ Isabel Cristina Celerino de Moraes Porto $(\mathbb{D})^{1,3^{*}}$
}

'Laboratory of Pharmaceutical and Food Analysis, Institute of Pharmaceutical Sciences, Federal University of Alagoas, Campus A. C. Simões, Maceió, Alagoas, Brazil ${ }^{2}$ Division of Clinical Dentistry, School of Dentistry, International Medical University, Kuala Lumpur, Malaysia ${ }^{3}$ Department of Restorative Dentistry, Faculty of Dentistry, Federal University of Alagoas, Campus A. C. Simões, Maceió, Alagoas, Brazil

\section{ABSTRACT}

Matrix metalloproteinases (MMPs) are enzymes that can degrade collagen in hybrid layer and reduce the longevity of adhesive restorations. As scientific understanding of the MMPs has advanced, useful strategies focusing on preventing these enzymes' actions by MMP inhibitors have quickly developed in many medical fields. However, in restorative dentistry, it is still not well established. This paper is an overview of the strategies to inhibit MMPs that can achieve a long-lasting material-tooth adhesion. Literature search was performed comprehensively using the electronic databases: PubMed, ScienceDirect and Scopus including articles from May 2007 to December 2019 and the main search terms were "matrix metalloproteinases", "collagen", and "dentin" and "hybrid layer". MMPs typical structure consists of several distinct domains. MMP inhibitors can be divided into 2 main groups: synthetic (syntheticpeptides, non-peptide molecules and compounds, tetracyclines, metallic ions, and others) and natural bioactive inhibitors mainly flavonoids. Selective inhibitors of MMPs promise to be the future for specific targeting of preventing dentin proteolysis. The knowledge about MMPs functionality should be considered to synthesize drugs capable to efficiently and selectively block MMPs chemical routes targeting their inactivation in order to overcome the current limitations of the therapeutic use of MMPs inhibitors, i.e., easy clinical application and long-lasting effect.

Keywords: Matrix metalloproteinases; Collagen; Dentin; Hybrid layer

\section{INTRODUCTION}

Successful outcome in adhesive dentistry means long-lasting restorations. However, there is considerable evidence that this target is not always reached and a large amount of research work has been carried out in aiming to improve the durability of resin-dentin bonding [1]. 


\section{ORCID iDs}

Izadora Quintela Souza de Moraes (iD https://orcid.org/0000-0001-9613-1766 Ticiano Gomes do Nascimento (iD) https://orcid.org/0000-0002-3856-8764 Antonio Thomás da Silva (iD

https://orcid.org/0000-0002-2975-7168 Lilian Maria Santos Silva de Lira (iD https://orcid.org/0000-0002-9191-5251 Abhishek Parolia (iD)

https://orcid.org/0000-0002-3364-6743 Isabel Cristina Celerino de Moraes Porto (iD https://orcid.org/0000-0003-0908-7424

Author Contributions

Conceptualization: Moraes IQS, Porto ICCM; Data curation: Moraes IQS, Porto ICCM, Nascimento TG, Parolia A; Formal analysis: Moraes IQS, Porto ICCM, Parolia A; Funding acquisition: Moraes IQS, Porto ICCM; Investigation: Moraes IQS, Silva AT, Lira LMSS; Methodology: Moraes IQS, Porto ICCM; Project administration: Moraes IQS; Resources: Moraes IQS, Porto ICCM; Supervision: Porto ICCM; Validation: Porto ICCM, Nascimento TG, Parolia A; Visualization: Moraes IQS Nascimento TG, Silva AT, Lira LMSS, Parolia A, Porto ICCM; Writing - original draft: Moraes IQS, Porto ICCM, Nascimento TG, Parolia A; Writing - review \& editing: Moraes IQS, Nascimento TG, Silva AT, Lira LMSS, Parolia A, Porto ICCM.
The integrity of the adhesive interface does not remain constant mainly due to the hydrolytic degradation of the adhesive monomers in a hybrid layer over a period of time and inability of an adhesive to fully permeate and cover the collagen mesh. Those unprotected demineralized collagen fibrils underlying the hybrid layer are exposed to proteolysis by host enzymes $[2,3]$.

Dentin is a mineralized tissue composed of inorganic apatite crystals embedded in an extracellular organic matrix (EOM). Type I collagen is the main component of the EOM, accounting for up to $90 \%$ of the organic material. In addition, various proteins collectively referred to as non-collagenous proteins constitute approximately $10 \%$ of the matrix and include proteoglycans, phospholipids and enzymes. Among dentin enzymes, matrix metalloproteinases (MMPs) have recently gained much attention because of their possible role in various physiological and pathological processes in dentin [4]. MMPs are zinc- and calcium-dependent endopeptidases involved in tooth development, dentin caries progression and hybrid layer degradation in composite resin restorations [5].

Bonding of resinous materials to dentin requires prior application of acid conditioners to promote a demineralized surface and expose the organic dentin matrix. In addition, the surface has to be fully infiltrated by monomers from the adhesive system, which will be polymerized to form a tooth-restoration interface called the hybrid layer [6]. However, this mechanism is not fully effective and collagen fibrils remain unprotected in some areas where monomer infiltration is deficient and are susceptible to the activity of MMPs [7].

Under physiological conditions, these proteases are secreted by odontoblasts during dentinogenesis and remain entrapped within the extracellular matrix of dentin in inactive form after matrix mineralization. The acid environment resulting from caries processes, including demineralization with phosphoric acid or acid resinous monomers derived from self-etching adhesives, activates different dentin MMPs $[8,9]$ that are responsible for the degradation of components of the extracellular matrix, mainly collagen type I $[9,10]$.

MMPs play an important role in the degradation process of the hybrid layer, leading to loss of strength in the resin-dentin bond, a problem that directly influences the longevity of adhesive restorations [7]. Thus, the inhibition of MMPs may represent a key piece of the troubleshooting for dentin adhesion, and this literature review aims to bring an overview of the strategies to inhibit MMPs and achieve a long-lasting of the hybrid layer.

Literature search was performed comprehensively using the electronic databases: PubMed, ScienceDirect and Scopus from May 2007 to October 2018. The main search terms were "matrix metalloproteinases", "collagen", and "dentin" and "hybrid layer". These keywords and terms were selected from key articles published in Medical Subject Headings (MeSH). They were enriched with additional terms during the electronic database searches. Articles published in English language were included. The search strategy was modified for each electronic database. A hand search of the reference lists of eligible articles was also performed to identify relevant articles. The citations thought to fulfill the inclusion criteria described above were assessed as full articles. Only articles published in the peer-reviewed journals were included. Although the review comprised primarily in vitro studies, in vivo studies were also included. From the selected articles evaluation of their cited references yielded additional papers suitable for inclusion in this review. 


\section{REVIEW}

\section{Hydrolytic degradation of adhesive polymers}

Adhesive systems are applied on a water-filled collagen network created after acid etching the dentin to infiltrate the spaces to form a hybrid substrate that is the bonding interface between tooth/restorative materials. To reach this aim, dentin should be kept hydrated, preventing the collapse of collagen fibrils. Water within the hybrid layer serves as a functional medium for the hydrolysis of the resin matrix. Hydrolysis and leaching of resin adhesives are considered the primary reason for resin degradation within the hybrid layer, contributing to the reduction of bond strength overtime [1]. Despite their hydrophobic characteristics, the resinous adhesives absorb water over time. This water plasticizes the polymer chains by acting as a molecular lubricant. The hydrophilic portion of the adhesives and the fluids sorption by material allows the flow of water, which forms large aqueous channels within the hybrid layer that work as the pathway to leachable unpolymerized monomers. The presence of water promotes the chemical hydrolysis of ester bonds in methacrylate materials. After that, local domains of the methacrylate network may get sufficiently degraded and/ or hydrophilic to permit access of esterases, which greatly accelerate ester-bond hydrolysis $[1,11]$. This phenomenon can be triggered not only with etch-and-rinse adhesives but also with self-etching adhesives [6,12].

\section{Collagen type I: structure and importance for bond stability}

The type I collagen molecule, the main component of the dentin organic matrix, consists of $2 \alpha 1$ and one $\alpha 2$ chain intertwined in a triple helix, which contains a rigid helical center with $\mathrm{N}$ and $\mathrm{C}$ globular terminals called telopeptides (Figure 1A). These individual strands are composed of a coding system formed by the presence of specific Gly-XY amino acid sequences where commonly Gly, X and $\mathrm{Y}$ are glycine, proline and hydroxyproline, respectively, which ensure that each area of the individual $\alpha$ chains can bind to 4 adjacent helical molecules, forming a structure that resembles a propeller called microfibril [13,14] (Figure 1B).

The molecules are staggered in a way that a pattern of repetition of hundreds of molecules is created every $67 \mathrm{~nm}$, typically known as the periodic D bandage of type I collagen. Staggered spaces between the ends of the successive collagen molecules produce the so-called gap zones, and areas, where multiple molecules are superimposed, represent the overlap zone, forming peaks and valleys and giving rise to the surface nano-structural roughness of microfibrils $[15,16]$. This repeated pattern may interconnect so that each valley (gap zone)

A

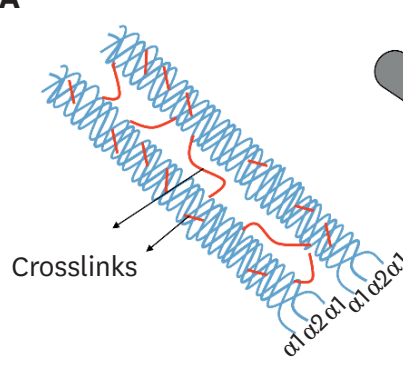

B

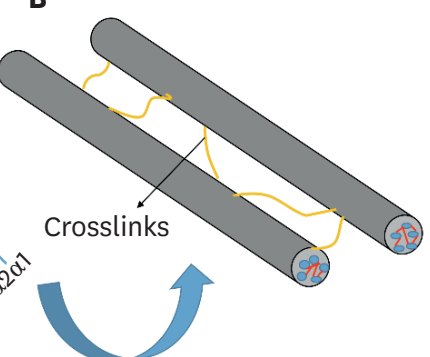

C

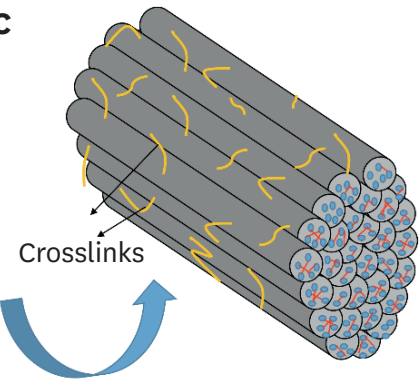

Figure 1. Structural organization of type I collagen fibril. (A) Two $\alpha 1$ and one $\alpha 2$ chains intertwine in a triple helix, giving rise to a collagen molecule. (B) Five adjacent helical molecules join together to form a microfibril. (C) Microfibrils meet in concentric bundles known as collagen fibrils. The crosslinking agents reinforce this bonding through the formation of crosslinks (represented in red and yellow) at the molecular and fibrillar levels, improving the mechanical properties of the demineralized collagen matrix. 
is adapted to the peaks (overlap zone) of an adjacent microfibril. Thus, microfibrils meet in concentric bundles, better known as collagen fibrils, measuring about $100 \mathrm{~nm}$ in diameter [17] (Figure 1C).

Collagen fibrils, mainly type I, make up 30\% of the volume of the hybrid layer that is the basis for a wide variety of restorative procedures currently performed in dentistry. The ultimate goal of adhesive procedures is the infiltration of monomers from adhesive systems and complete coverage of demineralized collagen fibrils. Thus, the network of collagen fibrils acts as an anchor to the resin, allowing the retention of adhesive restorations to the dentin $[6,18]$.

However, in regions where the infiltration of the monomers is less than the depth of dentin demineralization resulting from the application of acidic substances, the formation of void spaces occurs where the fibrils remain unprotected. Therefore, they are susceptible to the action of organic matrix proteases, which promote the slow but continuous degradation of the collagen fibrils that make up the hybrid layer, leading to loss of bond strength $[2,19]$.

MMPs are present in dentin and are known to degrade almost any component of the extracellular matrix, including collagen. Therefore, they have been considered to play a major role in the degradation of bare collagen fibrils within the hybrid layer [20].

\section{Metalloproteinases: structure and mechanism of action}

MMPs are a family of structurally related but genetically distinct enzymes that can degrade components of the extracellular matrix [21]. Twenty-four types of MMPs have already been identified (Table 1) and, because it was believed that each MMP had a specific substrate, the nomenclature was based on substrate specificity and molecular structure; thus the MMPs were classified as collagenases (MMP-1, MMP-8, MMP-13 and MMP-18), gelatinases (MMP-2 and MMP-9), stromelysins (MMP-3, MMP-10 and MMP-11), matrilysins (MMP-7 and MMP26), membrane type MMP (MMP-14, MMP-15, MMP-16, MMP-17, MMP-24 and MMP-25), and others (MMP-12, MMP-19, MMP-20, MMP-21, MMP-23, MMP-27 and MMP-28). However, it is now recognized that MMPs generally degrade multiple substrates, but the substrate-based classification is still widely used [22].

Structurally, these enzymes are divided into several domains, which differ in dependence on each subtype. However, most MMPs are composed of an $\mathrm{N}$-terminal propeptide, a catalytic domain, a hinge region and a C-terminal hemopexin domain [23]. The $\mathrm{N}$-terminal propeptide contains approximately 80 amino acids, guaranteeing the latency of the enzyme. The most important functional amino acid within the $\mathrm{N}$-terminal propeptide is cysteine, which interacts with zinc ions $\left(\mathrm{Zn}^{2+}\right)$ in the catalytic site through a thiol group and constitutes the cysteine switch. The catalytic domain contains $2 \mathrm{Zn}^{2+}$ and 2 or 3 calcium ions $\left(\mathrm{Ca}^{2+}\right)$. The first $\mathrm{Zn}^{2+}$ present in the active site is directly involved in catalytic processes. The second $\mathrm{Zn}^{2+}$ so-called structural $\mathrm{Zn}^{2+}$ and $\mathrm{Ca}^{2+}$, which are approximately $12 \mathrm{~nm}$ away from the $\mathrm{Zn}^{2+}$ at the catalytic site, are required to stabilize the structure of that domain. The $\mathrm{C}$-terminal domain is structurally similar to proteins in the hemopexin family and regulates the activity and specificity of the catalytic domain function. The catalytic domain and the $\mathrm{C}$-terminal are freely bound by a flexible proline-rich peptide bond (hinge region). The length of the hinge region is extremely variable and the specific function is not fully understood [24].

MMP-2 and -9 also contain a fibronectin-like domain that is responsible for the recognition of collagen so-called collagen-binding domain [25]. Collagen binding domains are the primary 
Table 1. Matrix metalloproteinases (MMPs) description, nomenclature and their substrate (modified from Hannas et al. [22])

\begin{tabular}{|c|c|c|c|}
\hline Group & MMPs & Nomenclature & Group substrate \\
\hline \multirow[t]{4}{*}{ Collagenases } & MMP-1 & $\begin{array}{l}\text { Collagenase 1, } \\
\text { fibroblast collagenase }\end{array}$ & $\begin{array}{l}\text { Types I, II, III, VII, X, XI collagens, gelatin, entactin, aggrecan, tenascin, perlecan, } \\
\text { vitronectin, } \alpha 2 \mathrm{Ma}\end{array}$ \\
\hline & MMP-8 & $\begin{array}{l}\text { Collagenase } 2 \text {, } \\
\text { neutrophil collagenase }\end{array}$ & $\begin{array}{l}\text { Types I, II, III, VII, X collagens, gelatin, aggrecan, entactin, tenascin, tissue factor } \\
\text { pathway inhibitor, } \alpha 2 \mathrm{Ma}\end{array}$ \\
\hline & MMP-13 & Collagenase 3 & $\begin{array}{l}\text { Types I, II, III, IV, VI, VII, X, IX, XIV collagens, gelatin, fibronectin, entactin, aggrecan, } \\
\text { tenascin }\end{array}$ \\
\hline & MMP-18 & $\begin{array}{l}\text { Collagenase } 4 \\
\text { (Xenopus collagenase) }\end{array}$ & Type I collagen \\
\hline \multirow[t]{2}{*}{ Gelatinases } & MMP-2 & Gelatinase A & $\begin{array}{l}\text { Types I, III, IV, V, VII, X, XI collagens, gelatin, elastin, fibronectin, laminin, aggrecan, } \\
\text { vitronectin }\end{array}$ \\
\hline & MMP-9 & Gelatinase B & $\begin{array}{l}\text { Types I, IV, V, VII, X, XI, XIV, XVII collagens, gelatin, elastin, fibronectin, laminin, } \\
\text { aggrecan, vitronectin, decorin, plasminogen, proTNF- } \alpha\end{array}$ \\
\hline \multirow[t]{3}{*}{ Stromelysins } & MMP-3 & Stromelysin 1 & $\begin{array}{l}\text { Types III, IV, V, IX, X, XI collagens, elastin, proteoglycans, laminin, fibronectin, gelatin, } \\
\text { fibrin/fibrinogen, aggrecan, vitronectin, perlecan, decorin, prolL-1bc, plasminogen, } \\
\text { Ecadherin, } \alpha 2 \mathrm{Ma} \text {, proTNF- } \alpha\end{array}$ \\
\hline & MMP-10 & Stromelysin 2 & $\begin{array}{l}\text { Types III, IV, V, IX, X, XI collagens, proteoglycans, laminin, fibronectin, gelatin, } \\
\text { aggrecan, elastin, fibrin/fibrinogen, vitronectin }\end{array}$ \\
\hline & MMP-11 & Stromelysin 3 & Unknown \\
\hline \multirow[t]{2}{*}{ Matrilysins } & MMP-7 & Matrilysin 1, PUMP-1 & $\begin{array}{l}\text { Elastin, proteoglycans, laminin, fibronectin, gelatin, types I, III, IV, V, IX, X, XI } \\
\text { collagens, fibrin/fibrinogen, tenascin, vitronectin, pro } \alpha \text {-defensin, decorin, E-cadherin, } \\
\text { plasminogen, proTNF- } \alpha\end{array}$ \\
\hline & MMP-26 & Matrilysin 2 & Fibronectin, fibrinogen, gelatin, type IV collagen, laminin-1 \\
\hline \multirow[t]{6}{*}{$\begin{array}{l}\text { Membrane-type } \\
\text { MMPs }\end{array}$} & MMP-14 & MT1-MMP & $\begin{array}{l}\text { Types I, II, III collagens, gelatin, fibronectin, tenascin, perlecan, nidogen, vitronectin, } \\
\text { factor XII, fibrin, proTNF- } \alpha \text {, laminin, cartilage proteoglycan core protein, } \alpha 2 \mathrm{Ma}\end{array}$ \\
\hline & MMP-15 & MT2-MMP & $\begin{array}{l}\text { Laminin, fibronectin, tenascin, nidogen, entactin, gelatin, aggrecan, vitronectin, } \\
\text { proTNF-ab, transglutaminase }\end{array}$ \\
\hline & MMP-16 & MT3-MMP & $\begin{array}{l}\text { Gelatin, type III collagen, perlecan, fibronectin, vitronectin, aggrecan, } \\
\text { transglutaminase }\end{array}$ \\
\hline & MMP-17 & MT4-MMP & Gelatin, fibrin/fibrinogen, $\alpha 2 \mathrm{Ma}$, proTNF- $\alpha$ \\
\hline & MMP-24 & MT5-MMP & Proteoglycan, type I collagen, fibronectin, laminin \\
\hline & MMP-25 & MT6-MMP & Gelatin, type IV collagen, fibronectin \\
\hline \multirow[t]{7}{*}{ Others } & MMP-12 & $\begin{array}{l}\text { Macrophage elastase } \\
\text { MMP-12 }\end{array}$ & $\begin{array}{l}\text { Types I, IV collagens, (Metallo elastase) aggrecan, decorin, gelatin, elastin, fibronectin, } \\
\text { fibrin/fibrinogen, laminin, proteoglycan, vitronectin, plasminogen, } \alpha 2 \mathrm{Ma}\end{array}$ \\
\hline & MMP-19 & RASI-1 & $\begin{array}{l}\text { Types I, IV collagens, fibronectin, gelatin, tenascin, casein, laminin, entactin, aggrecan, } \\
\text { nidogen, nascin-C }\end{array}$ \\
\hline & MMP-20 & Enamelysin & $\begin{array}{l}\text { Amelogenin, casein, gelatin, fibronectin, types IV, XVIII collagens, laminin, tenascin C, } \\
\text { aggrecan }\end{array}$ \\
\hline & MMP-21 & Xenopus-MMP & Undetermined \\
\hline & MMP-23 & $\begin{array}{l}\text { CA-MMP, type II } \\
\text { transmembrane-type MMP }\end{array}$ & Undetermined \\
\hline & MMP-27 & C-MMP & Type II collagen, gelatin, fibronectin \\
\hline & MMP-28 & Epilysin & Casein \\
\hline
\end{tabular}

MMPs based on substrate specificity and molecular structure. Groups of MMPs are listed with their trivial names.

sites of interaction with collagen and gelatin; they also mediate elastin binding. Therefore, they are required for the cleavage of collagen and elastin [26].

In the human body, MMPs are not only involved in negative actions but also play a significant protective role in human physiology. MMPs are important as regulators of postnatal development and remodeling and repair of tissues in response to injury, infection or disease [27]. In the oral environment, these enzymes are related to periodontal diseases, caries progression, pulpal inflammation and cancer. They may also be involved in the release of dentinal growth factors forming tertiary dentin in response to external aggression, tissue destruction in response to pulpal inflammation and, more recently, in the demineralized collagen decomposition of the hybrid layer of composite resin restorations [28,29].

Zymographic analyses have demonstrated that MMP-2, MMP-8, MMP-9, MMP-13 and MMP20 are present in the dentin organic matrix. Of these, MMP-2 and MMP-9 are the most 
prevalent forms in dentin; MMP-2 is present in larger amounts than other forms of MMPs in human dentin [30,31].

In the mineralized matrix, the presence of apatite crystals on collagen fibrils and their non-collagenous proteins probably block the access of the catalytic site of the collagen, thus leaving the inactive MMPs. However, the acidic environment generated by adhesive procedures and caries processes removes the apatite crystals that cover the collagen and disrupts cysteine-zinc coordination, which is then lost; as a consequence of this, activation of latent proteases occurs [9,32,33] (Figure 2A). Although a small fraction of these proteases can be extracted by acids, most remain bound to the matrix in their active form, where they can slowly hydrolyze the collagen matrix [34] and represent a threatening to the integrity of the dentin/resin interface resulting on reduced durability of the adhesive restorations over time.

Collagenase cleaves the triple helical collagen molecules into 2 fragments of one-quarter and 3-quarters length; the first quarter contains the $\mathrm{C}$-terminal part of the collagen molecule and the second 3-quarters contain the $\mathrm{N}$-terminal portion [35] (Figure 2B). Collagen loses its triple helical conformation and can then be degraded by gelatinases MMP-2 and MMP-9 [21]. MMP-2 and - 9 attack the non-helical fragments and reduce them to even smaller peptide fragments. The binding sites of collagen to MMPs are very similar to the catalytic site of these enzymes. Thus, the collagen-binding domain of MMP-2 and -9 binds to a short segment of the collagen $\alpha 1$ chain [36]. After binding to the substrate, the water molecule that is bound to the zinc of the catalytic domain attacks the substrate and, through the transfer of protons, promotes the cleavage of the peptides [25]. It is speculated that endogenous MMPs in the dentin matrix bind to the collagen peptides via their hemopexin-like domains (MMP-1, -8) and/or their fibronectin-like domains (MMP-2, -9) [34].

A

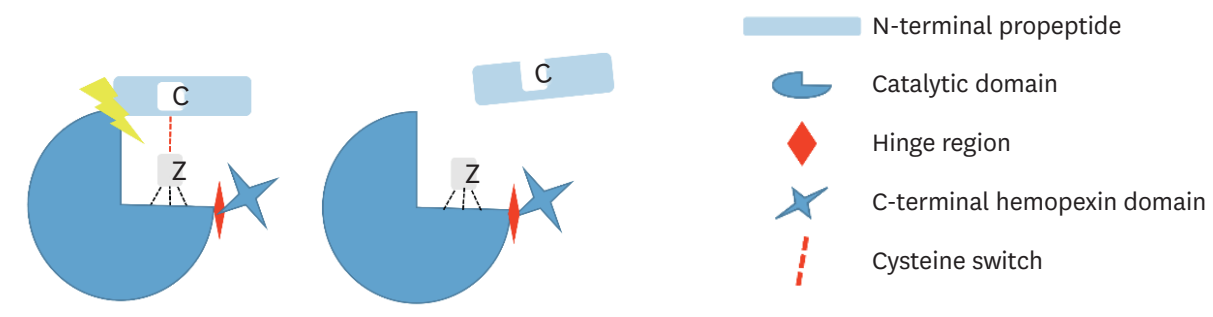

B

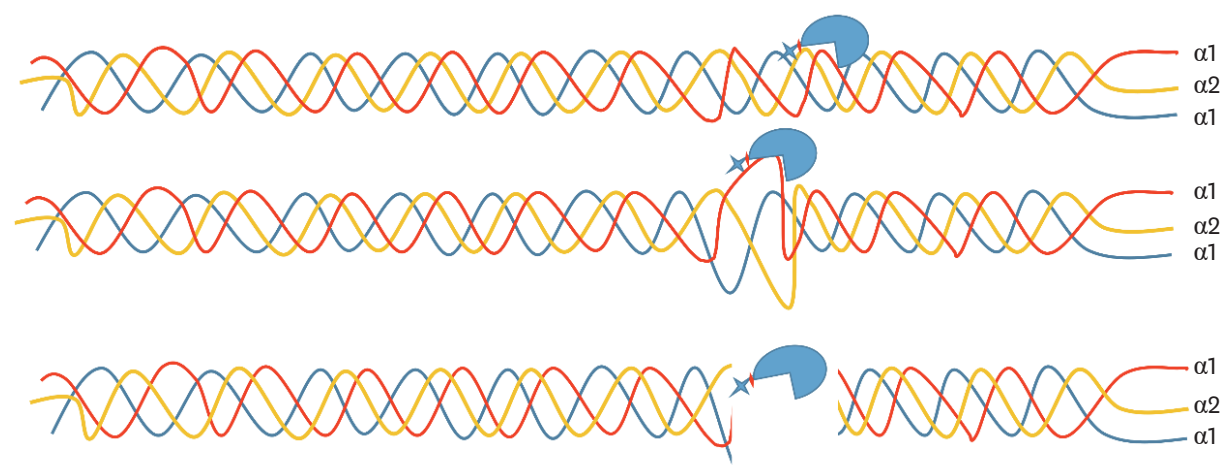

Figure 2. Structure and activation of metalloproteinases. (A) Metalloproteinases are composed of an N-terminal propeptide, catalytic domain, hinge region and C-terminal hemopexin domain. Its activation occurs when cysteine-zinc coordination is lost as a consequence of the activation of the proteases that were in latent form (proenzymes) in the tissue. (B) After activation, collagenase cleaves the collagen molecules, causing them to lose the triple helical conformation, resulting in 1/4 and 3/4 length fragments that will be slowly hydrolysed by the gelatinases. 
Clinically, the degradation of the adhesive interface over time causes marginal discoloration, secondary caries and subsequent loss of retention. As a consequence, it is necessary to replace the restorations within a relatively short time. Therefore, in order to achieve an effective and stable bond, the preservation of dentin collagen is critical, because collagen represents the main organic component of the dentin matrix and plays a key role in bond strength $[37,38]$.

\section{Strategies to improve the stability of the dentin/resin bonding}

In dentistry, there is concern about the long-term stability of the adhesive interface [22]. Synthetic or natural bioactive agents, which inhibit the endogenous enzymes of the organic matrix of collagen, have been used in the attempt to produce a strong and durable adhesive interface. The use of these substances may help to preserve the hybrid layer and increase the durability of the resin-tooth bond [39]. These agents can be applied in different ways: incorporated in the acid for dentin etching [40,41], included into the composition of the adhesive system [42-45] or applied as a solution directly on the dentin surface after the acid treatment remaining in contact with the surface of the dentin [46-49]. MMPs inhibitors act by different mechanisms such as by chelating cations [50-52], collagen crosslinking [53-55] and competitive inhibition for active sites of the collagen molecule $[26,56,57]$.

\section{Inhibition by chelating}

Most of these agents act by inhibiting MMP activity by chelating $\mathrm{Zn}^{2+}$ from the active site [50]. Chlorhexidine (CHX) is the most well-documented MMP inhibitor. It has been shown that when applied after acid etching or incorporated into adhesive systems, it can preserve the integrity of the demineralized collagen matrix and increase the strength of the resin-dentin bond over time $[58,59]$. This substance acts as a non-specific inhibitor of MMPs, since it is capable of altering the three-dimensional structure of these enzymes and chelating the metal ions $\left(\mathrm{Ca}^{2+}, \mathrm{Zn}^{2+}\right)$, which are necessary for the activation of its enzymatic function [56]. CHX is able to inactivate all MMPs in dentin even at low concentrations such as $0.02 \%$ [60]. Since the mechanism of CHX binding to dentin is only electrostatic [61], there is concern that CHX may have been displaced by cations from dentinal fluid or saliva loosening their anti-proteolytic feature. This may explain recent observations of da Silva et al. [58] and Montagner et al. [49] that showed CHX maintains the stability of the resin-dentin bond only up to 12 months. Therefore, the time of action of CHX as an inhibitor of MMPs is a limiting factor for its use [49,51]. To overcome this issue, de Menezes et al. [43] added a CHX modified release system using clay as a reinforcing agent and release modulator to an adhesive. CHX + clay showed better MMPs inhibition capacity than CHX and maintained the bone strength even after 18 months.

Some studies have used CHX diacetate instead of CHX digluconate because it preserved the resin-dentin bonding and did not interfere with water sorption, solubility or conversion degree of adhesive systems [58,62]. The main difference between these 2 chemicals is that CHX digluconate is only available as an aqueous solution while CHX diacetate is available as a powder. The addition of CHX digluconate to adhesives means adding water to the formulation, which may spoil the properties of the adhesive system. A new approach was attempted introducing a novel drug-delivery approach to demineralized dentin substrates and the resin-dentin interface with Poly( $\varepsilon$-caprolactone) CHX-loaded nanocapsules (nanoPCL/CHX). The authors showed infiltration retention of nano-PCL/CHX (125:25 and 125:50) inside dentinal tubules at depths of approximately $5 \mu \mathrm{m}$ to10 $\mu \mathrm{m}$ [63].

In vivo, the short-term results are encouraging. Ricci et al. [64] and Brackett et al. [48] showed a beneficial effect of CHX on slow down the rate of resin-dentin bond degradation in the first 
months of function. But after 2 years, clinical trials showed that the addition of CHX into adhesive systems or its use as dentin pretreatment did not add clinical advantages and did not improve the clinical durability of adhesive restorations [65-68].

Similar to CHX, ethylenediaminetetraacetic acid (EDTA) and tetracyclines act by non-specific chelation of $\mathrm{Zn}^{2+}$ and $\mathrm{Ca}^{2+}$ cations [51]. Tetracyclines have been shown to inhibit collagen degradation and bone loss in periodontitis. The binding of calcium and zinc to the carbons -11 and -12 of tetracycline seems to be involved in this mechanism of inhibition [69], while EDTA contains 4 carboxylic acid groups and at neutral pH, it acts as a chelating agent [70].

Galardin, a synthetic MMP inhibitor, acts specifically by $\mathrm{Zn}^{2+}$ chelation located in the catalytic domain, selectively inhibiting MMP-2, -3, -8 and -9, in contrast to the mechanism of action of $\mathrm{CHX}$. This inhibitor has a structure similar to collagen, which facilitates its binding to the active site of MMPs. Galardin inhibits the proteolytic activity in the demineralized dentin in a similar way to $\mathrm{CHX}$ for a period of 12 months, even when used in a concentration of approximately 10 to 100 times lower $(0.2 \mathrm{mM})$ for 30 seconds. This result supports the concept that specific inhibitors act at very low concentrations [52]. Therefore, the use of galardin as an inhibitor of dentin MMPs may be a clinically relevant alternative to improve the stability of the hybrid layer. However, researchers still are searching for products that keep its effect lasts longer.

Quaternary ammonium compounds (QACs) are a group of cationic antimicrobial agents that can bind to negatively charged phosphate and carboxylic groups in hydroxyapatite and collagen, respectively, exhibiting similar anti-MMP action to CHX [71]. However, the nature of these electrostatic interactions is weak and similarly to biguanides, QACs are water-soluble molecules and may leach out of adhesive interface, reducing their anti-proteolytic effect overtime [72].

Daood et al. [73] synthesized 2\%, 5\% and 10\% quaternary ammonium silane (QAS) and showed that QAS inhibited endogenous MMPs and cysteine cathepsins. Later, Daood et al. [74] used QAS on etched dentin before the bonding procedure. The use of a tetrafunctional organosilane as an anchoring unit for the antimicrobial trialkoxysilane molecules enables a three-dimensional network to be formed once condensation has been completed within the dentinal substrate. This minimizes the possibility for QAS molecules to leach out of the resindentine interface and gives a considerably longer activity. The 2\% QAS is a good inhibitor of dentin proteases and could be an alternative for $2 \%$ CHX as MMPs inhibitor to improve the durability of the resin-dentin bond [74].

Benzalkonium chloride (BAC) is an antimicrobial agent containing a quaternary ammonium group. It has demonstrated inhibitory potential against endogenous proteases [42].

It is commercially available as an etchant (phosphoric acid-containing BAC $1.0 \mathrm{wt} \%$ ) with controversial results [40,72]. Sabatini et al. [72] showed the effectiveness of BAC in preventing the bonding interface breakdown after 6 months. Contrary, on El Gezawi et al. [40] study, BAC-etch did not improve bond stability after 6 months. The etchant possesses anti-proteolytic properties. However, rinsing off the etchant technique limits the BAC available and in consequence its effect. Comba et al. [42] added BAC into the primer and adhesive formulation to get a more effective delivery system. Although the BAC-doped adhesive showed inhibitory property on dentin MMPs at baseline, this activity was not reflected by the bond strength results after 6 months. In general, BAC should be extensively tested before translation to clinical use. 
A monomer in the family of QACs 12-methacryloyloxy-dodecyl-pyridinium bromide is a chemical incorporated into commercially available adhesives and showed dentin MMP inhibition similar to CHX but required higher concentrations. The advantage over other MMPs inhibitors is that it can copolymerize with adhesive monomers. So, its effect on MMPs can be expected to maintain for years [71,72]. Long-term clinical studies are necessary to validate that assumption.

Alcohols can also act as MMPs inhibitors. As hydrolases, MMPs require water for their proteolytic activity. Specifically, they add water to specific peptide bonds breaking large peptide chains into smaller ones [30,75]. Water is present in adhesives and in CHX solution (as the vehicle for its delivery), which results in increased water content into the hybrid layer. Tezvergil-Mutluay et al. [75] have tested a series of alcohols (methanol, ethanol, propanol, butanol, pentanol, heptanol and octanol, the ethanol ester of methacrylic acid and propanediol). Alcohols were able to inhibit human recombinant MMP-9 and the endogenous proteases of dentin matrix in a dose-dependent manner. Based on the molar concentration required to inhibit rhMMP-9 50\%, 2-hydroxyethyl methacrylate (HEMA), 3-hexanol, 3-heptanol and 1-octanol showed the strongest inhibition. The results indicated that alcohols with 4 methylene groups inhibit MMPs more effectively than methanol or ethanol.

The mechanism of MMP inhibition of these alcohols seems to involve hydrophobic forces since the inhibitory activity of alcohol is inversely related to their concentration. High alcohol concentrations may denature enzymes by removing water from the enzyme structure, causing their denaturation. The presence of bound water prevents interpeptide hydrogen bonding within the peptide chains of enzymes. Removal of that water allows rapid interpeptide hydrogen bonding that can disrupt the tertiary structure that is necessary for enzyme activities. Some proteins can be recovered when the alcohol is removed and the proteins are rehydrated. Other proteins are unable to reconstitute their original tertiary structure [75].

In this context, ethanol wet-bonding was introduced in order to address a solution for improving resin-dentin bond durability. This technique is based on applying ethanol $100 \%$ or in ascending concentrations (50\%, 70\%, 80\%, 95\% and $3 \times 100 \%$ ) on demineralized dentin [76]. It was proposed aiming to remove the remaining water, creating wider interfibrillar spaces that allow the monomers to infiltrate deeply through the collagen matrix. However, ethanol wet bonding causes collapse and shrinkage of collagen fibrils and consequently poor resin infiltration. In addition, ethanol is not so effective in inhibiting MMPs [76]. So, the immediate benefits of the ethanol-bonding technique observed in the laboratory setting were not confirmed when the same protocol was performed in vivo [76].

\section{Collagen crosslinking}

In addition to the use of metalloproteinases inhibitors, collagen crosslinking agents have been used in an attempt to improve the mechanical properties of the demineralized collagen matrix (Figure 1C). This group includes proanthocyanidin (PA) [53,77], glutaraldehyde [78], baicalein [55], hesperidin [45], riboflavin [54,79], resveratrol [46] and quercetin [46].

PA can simultaneously perform a protease inhibition function, in addition to the collagen crosslinking function. The crosslinking effect of PA is attributed to its interaction with proteins rich in proline, which promotes the formation of intermolecular crosslinks within the collagen matrix and acts to increase the mechanical stability of the matrix [53]. Although CHX can successfully prevent degradation of the collagen matrix, it has no effect on the 
reinforcement of demineralized collagen fibrils [80]. Liu et al. [77] showed that 2\% PA applied on the demineralized dentin for 30 seconds was able to increase the collagen resistance to degradation by MMPs.

When added to $10 \%$ phosphoric acid, PA did not compromise adhesion efficiency in enamel and dentin, and produced a stable dentin bond after six months of aging in water. Stability of the resin/dentin interfaces produced with this acid can be attributed to several factors that function synergistically, such as the ability to interact with collagen even in an acidic environment; their ability to inactivate the catalytic site of proteases and the increased resistance of collagen fibrils that render them less susceptible to degradation by proteases [38]. However, the long-term performance of the experimental material was not observed in this study.

Glutaraldehyde has also been used with the goal of improving the properties of demineralized dentin. Its ability to irreversibly bind proteins and increase the modulus of elasticity of collagen fibrils is of great interest in enhancing the collagen structure. Moreover, its ability to react chemically with collagen and resin components, such as HEMA, can also contribute to the penetration of the adhesive system and facilitate the wettability of the dentin substrate [78]. However, glutaraldehyde has high cytotoxicity and therefore, the use of other collagen crosslinkers with no or low toxicity is highly desirable [81].

Baicalein is one of the major flavonoids in Scutellaria baicalensis which inhibits the activity of MMP-2 and MMP-9 via PI3K/AKT, P38-MAPK-NF- $\mathrm{KB}$ and MAPK-ERK1/2 signal pathways. Moreover, baicalein and PAs have a similar molecular structure with phenolic hydroxyl functional groups, suggesting that they have comparable crosslinking properties. Used as dentin preconditioner followed by an etch-and-rinse adhesive system, it effectively improves the resin-dentin bonding durability [55]. Hesperidin is also a flavonoid. It was tested as MMPs inhibitor by Islam et al. [45], and it was effective in preserve dentin collagen what favors tissue remineralization due to keeping the collagen scaffold.

Riboflavin is a suitable agent for the crosslinking of dentin collagen because of its biocompatibility and its ability to produce free radicals when photo-activated in a spectrum ranging from ultraviolet (UV) to visible light $(270 \mathrm{~nm}, 366 \mathrm{~nm}$ and $445 \mathrm{~nm})$. These free radicals, or so-called reactive oxygen species, such as $\mathrm{O}_{2}$ and $\mathrm{O}_{2}{ }^{-}$, are released when the riboflavin is photo-activated and light is absorbed, forming covalent crosslinks between the adjacent collagen molecules. Riboflavin enhances immediate bond strength to dentin, stabilizes the adhesive interface and inhibits dentin MMPs, enhancing the durability of resin-dentin bonds. Although the use of ultraviolet A (UVA) is effective for photo-activation of riboflavin for collagen crosslinking, safety issues regarding the use of UVA and its practicality for dental use should be considered. Conventional blue halogen light units may be a possible alternative to replace UVA light sources because of their ready availability and safe ease of use in dentistry [54,79]. However, further studies investigating the use of visible light sources, which act in wide amplitude between UV and blue light, with coverage of the different absorption peaks of riboflavin are recommended, in order to better evaluate the penetration of visible light and activation depths of the riboflavin in the dentin matrix and its interaction with MMPs and monomers [54].

\section{Competitive inhibition for active sites of the collagen molecule}

Another mechanism proposed in the attempt to inhibit the action of MMPs is the competitive inhibition through the binding to the active sites of the collagen molecule. It has been demonstrated that $\mathrm{Zn}^{2+}$ or other divalent metals may reduce the expression of some MMPs. 
$\mathrm{Zn}^{2+}$ can be considered a competitive inhibitor of MMPs, exerting a protective effect through binding to the collagen-sensitive cleavage sites of the metalloproteinases. It seems that subtle conformational changes occur in collagen after zinc binding and lead to the protection of metalloproteinases cleavage sites [56]. The concentration of $\mathrm{Zn}^{2+}$ around matrix-bound MMPs may be very important in determining their activity on dentin collagen $[56,82]$.

Osorio et al. [56] showed by evaluation of carboxyterminal telopeptide concentration of type I collagen (ICTP) released during degradation of collagen showed that the use of an adhesive loaded with zinc oxide $(\mathrm{ZnO})$ nanoparticles reduced and stabilized the degradation of collagen for up to 4 weeks without negative interfering in dentin bond strength. However, it is crucial to analyze the ability of nanoparticles to release ions in a sustained manner and to determine the right concentrations of $\mathrm{Zn}^{2+}$ to be used without causing toxicity [83]. Since zinc oxidecontaining materials have been widely used in the dentin interface over time, it is expected that new adhesive systems with zinc oxide will also be compatible, making their use viable.

Santamaria et al. [84] reported a series of 4,4'-biphenylsulfonamides as selective inhibitors of MMP- 2 and -13 and showed that these molecules do not bind the catalytic zinc of MMPs. The authors suggest that this class of molecules binds to a catalytic subsite, possibly the S1'pocket. All the compounds had a bent 4 -substituted phenyl ring linked by $1 \mathrm{C}$ bridge to the 4'-position of a 1,1'-biphenyl-4-sulfonamide scaffold and, in general, resembled the structure of some previously reported MMP-13 non-zinc binding inhibitors. Two of the characterized inhibitors (11 and 19) act as non-competitive inhibitors, whereas the para-methyl ester derivative 13 behaves as a competitive inhibitor.

The study conducted by Xu et al. [26] identified a collagen peptide, which can bind specifically to the collagen-binding domain of MMP-2. Binding of the peptide to this domain blocks the positioning of substrate molecules relative to the catalytic site and thereby inhibits the activities of MMP-2.

\section{Inhibitors with multiple action mechanisms}

Carbodiimides have been used as an alternative to glutaraldehyde because they do not contain potentially cytotoxic aldehyde residues. It inhibits MMPs by inactivating the active sites by reducing their molecular mobility and also improves the resistance of cross-linked collagen matrices to degradation by inducing exogenous crosslinks and thereby increasing their stiffness. Their non-specifically crosslink proteins, activating the carboxylic acid groups of glutamic and aspartic acids to form an O-acylisourea intermediate. The latter reacts with the $\varepsilon$-amino groups of lysine or hydroxylysine to form amide crosslinking, leaving the urea as the terminal by-product. Carbodiimides are an example of crosslinking agents in which the peptides are crosslinked to one another without introducing additional linking groups. Thus, this crosslinking agent increases the mechanical properties of the collagen matrix and thus renders resin-dentin bonds more durable [85]. In addition, this substance is a potent inhibitor of MMPs. Its inhibitory effect, due to reduced molecular mobility, is much faster than the crosslinking effect of collagen [86]. Therefore, it seems that the inactivation of MMP by substances such as carbodiimide will have a longer-lasting effect than the exclusively MMP inhibiting substances, possibly due to the combined action of these 2 mechanisms of action that favor the maintenance of the hybrid layer integrity.

Resveratrol and quercetin as polyphenols can inhibit MMP activity by zinc chelation [12]. They have a high complexation affinity to metal ions, and zinc is essential for MMP activity [87]. 
Quercetin itself increases the expressions of tissue inhibitor of metalloproteinase (TIMP-2) [88]. Resveratrol and quercetin suppress prostaglandin-E synthesis by inhibiting the activity of cyclooxygenase-2 enzyme (COX-2) and also inhibit COX-2 gene transcription. It may be particularly useful because the over-production of the COX-2 induces MMP release. Gotti et al. [89] showed that a total-etch 2-step quercetin-doped adhesive $(5.0 \mathrm{w} \%$ ) significantly increased the bond strength after 180 days. Porto et al. [46] tested quercetin and resveratrol as pretreatment of etched dentin. Comparisons between 1 day and 120 days microtensile bond strength measurements showed that after 120 days the results were similar to or higher than CHX.

Green tea has also been proposed as a natural inhibitor of MMPs. This inhibitory action has been attributed mainly to polyphenols in the tea, especially epigallocatechin gallate [90]. This polyphenol is capable of stabilizing the collagen chain by increasing the number of crosslinks of the collagen fibrils and reducing biodegradation of collagen. The mechanism of action of epigallocatechin gallate is complex, involving multifunctional activities such as downregulation of endogenous protease expression, inactivation of protease and prevention of free access of collagenase to sites active in collagen chains [39].

Monteiro et al. [90] showed that although the application of the green tea solution reduced bond strength after 24 hours, compared to the control. Contrary, after 6 months, the union strength values did not present statistically significant differences compared to the control groups and CHX. In another study, when aqueous extract of epigallocatechin gallate was applied for a shorter time than green tea solution, there was no negative interference in the immediate bond strength and the stability of the adhesive interface was maintained ( 6 and 12 months) similar to CHX [39]. Probably the negative results observed in the short-term evaluation ( 24 hours) in the study conducted by Monteiro et al. [90] could have been due to the interference of other components of green tea that were not present in the extract of epigallocatechin gallate isolated from green tea.

The inhibition of MMPs has been shown to reduce the degradation of the adhesive interface when applied directly to the dentin as a pre-treatment. However, this strategy increases the clinical steps of adhesive application [9]. When substances were incorporated into components of the adhesive systems, concerns such as substantivity issues, which restricted the time of action of these inhibitors and their release from polymerized resin matrices, which could limit their inhibitory potential [91]. Thus, results obtained with these strategies are not linear, showing neutral, positive or negative effects on bonding stability [58], most likely due to the different techniques of application and the wide variety of substances used for that. Thus, more studies should be conducted to better clarify the details about controlling the action of MMPs, reinforcement collagen by the crosslinking agents, as well as long-term tests to observe how long the protective effect against MMPs will last, and thus targeting the results to identify ideal conditions for its use that support its clinical indication. From future research, new types of adhesive systems could be developed and are likely to be available in the near future, improving the quality of dentin adhesion techniques, providing a more stable adhesion, capable of resisting collagenolytic degradation, resulting in restorative procedures with higher quality and longevity.

\section{Clinical remarks and perspectives on further researches}

Data from studies included in this review have demonstrated that endogenous enzymes contained in the dentin are involved in the failure of adhesive restorations [48,58,59,64]. Slowing down or preventing the irreversible destruction of the teeth organic matrix would allow obtaining long-lasting restorations. A promising overview of MMPs inhibitors activity 
coming from in vitro studies had been found in this review. However, a lack of long-term clinical trials was noticed. Table 2 resumes the researches on exogenous MMP inhibitors, their mechanism of action, type of study, and period of the test.

Table 2. Matrix metalloproteinases (MMPs) inhibitors and strategies to improve the stability of the dentin/resin bonding

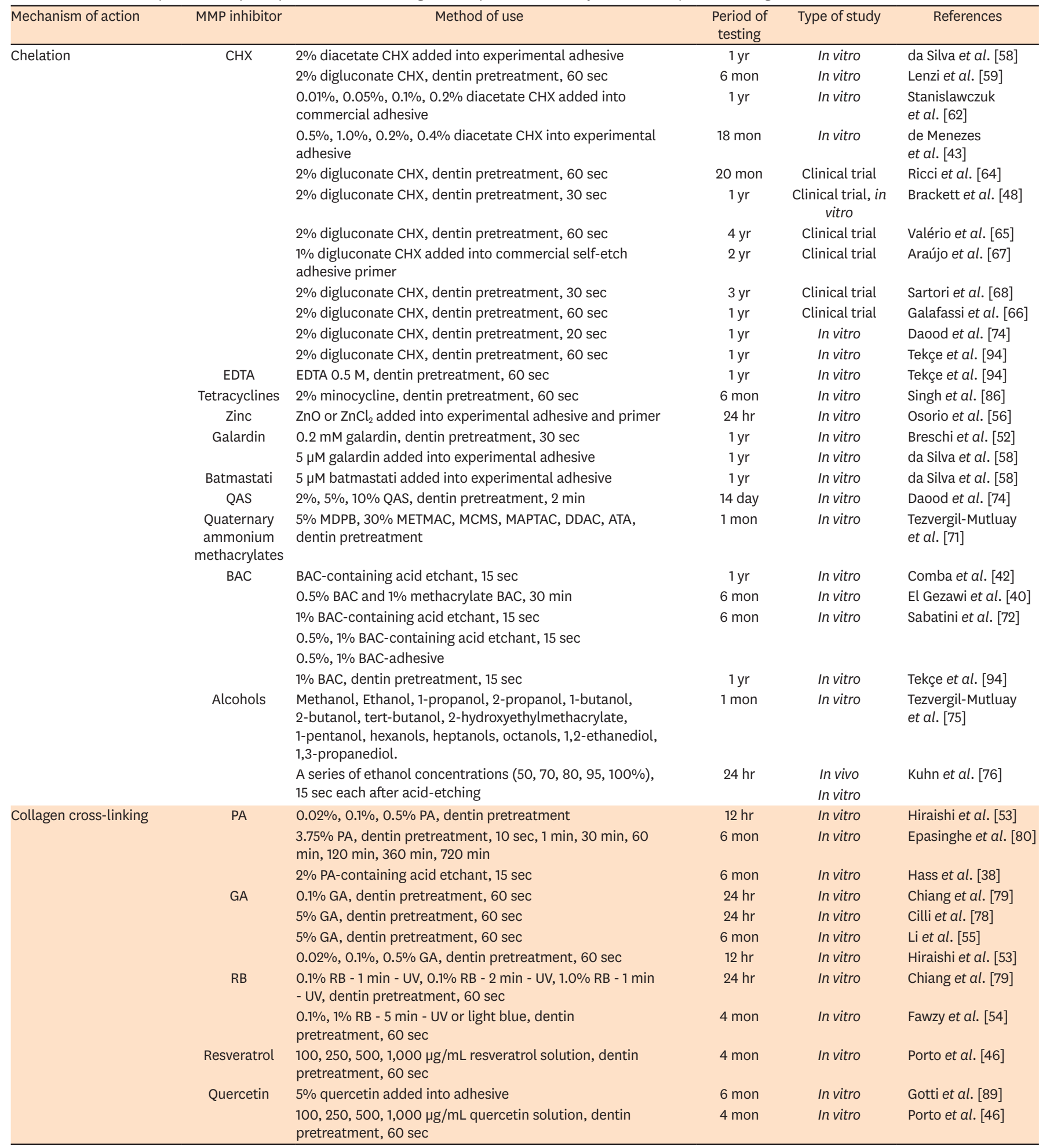


Table 2. (Continued) Matrix metalloproteinases (MMPs) inhibitors and strategies to improve the stability of the dentin/resin bonding

\begin{tabular}{|c|c|c|c|c|c|}
\hline Mechanism of action & MMP inhibitor & Method of use & $\begin{array}{l}\text { Period of } \\
\text { testing }\end{array}$ & Type of study & References \\
\hline \multirow{3}{*}{$\begin{array}{l}\text { Multiple action } \\
\text { mechanisms (by } \\
\text { inactivating the active } \\
\text { sites and improving the } \\
\text { resistance of cross-linked } \\
\text { collagen matrices) }\end{array}$} & Carbodiimides & $\begin{array}{l}0.01,0.02,0.05,0.1,0.3 \mathrm{M} \text { carbodiimide, dentin } \\
\text { pretreatment, } 60 \mathrm{sec}\end{array}$ & 1 mon & In vitro & $\begin{array}{l}\text { Tezvergil-Mutluay } \\
\text { et al. [34] }\end{array}$ \\
\hline & & $1 \mathrm{M}$ carbodiimide solution, dentin pretreatment, $60 \mathrm{sec}$ & 6 mon & In vitro & Singh et al. [86] \\
\hline & & $0.1 \%$ EGCG solution, dentin pretreatment, $60 \mathrm{sec}$ & $1 \mathrm{yr}$ & In vitro & Neri et al. [39] \\
\hline
\end{tabular}

CHX, chlorhexidine; EDTA, ethylenediaminetetraacetic acid; QAS, quaternary ammonium silane; METMAC, [2(methacryloyloxy)ethyl] trimethylammonium chloride; MCMS, methacryloyl choline methyl sulfate; MAPTAC, [3(methacryloylamino)propyl] trimethylammonium chlorid; DDAC, diallyldimethylammonium chloride; ATA, 2-acryloxyethyltrimethylammonium chloride; MDPB, 12-methacryloyloxydodecylpyridinium bromide; BAC, benzalkonium chloride; PA, proanthocyanidin; GA, glutaraldehyde; RB, riboflavin; Zn, zinc; EGCG, epigallocatechin-3-gallate.

New approaches have attempted to address some of the drawbacks of classic MMP inhibitors such as nanocarriers for drug delivery [43]. Chemicals were added to commercial and experimental adhesives [42-44] and researches have been carried out with methacrylamidebased monomers as novel materials for use in dental adhesives, hydrolytically stable, showing increased resistance to enzymatic degradation $[92,93]$.

Most of the preclinical studies on exogenous MMP inhibitors still are in the early stages and some of them showed limited success. Moreover, the great difficulty in translating laboratory into clinical researches is the study design regarding the selection of concentrations, drugreleasing, and period of the test. The lack of standardized methodologies makes rough the evaluation of its efficacy.

New MMP inhibitors with higher selectivity and substantivity could improve the specificity of MMP inhibitors targeting specific MMPs involved in dentin proteolysis. Besides, because of the differences in the proteolytic activities of different MMPs towards different substrates, it is critical to examine different MMP inhibitors in various regions of dentin and at different stages of the caries disease. Urge to investigate its ability against MMPs action through more in vivo research with extended follow-up.

\section{CONCLUSION}

Selective inhibitors of MMPs promise to be the future for specific targeting of preventing dentin proteolysis. The knowledge about the MMPs functionality should be considered to synthesize drugs capable to efficiently and selectively block the MMPs chemical routes targeting their inactivation in order to overcome the current limitations of the therapeutic use of MMPs inhibitors, i.e., easy clinical application and long-lasting effect.

\section{REFERENCES}

1. Frassetto A, Breschi L, Turco G, Marchesi G, Di Lenarda R, Tay FR, Pashley DH, Cadenaro M. Mechanisms of degradation of the hybrid layer in adhesive dentistry and therapeutic agents to improve bond durability--A literature review. Dent Mater 2016;32:e41-e53. PUBMED | CROSSREF 
2. Anchieta RB, Machado LS, Sundfeld RH, Reis AF, Giannini M, Luersen MA, Janal M, Rocha EP, Coelho PG. Effect of partially demineralized dentin beneath the hybrid layer on dentin-adhesive interface micromechanics. J Biomech 2015;48:701-707. PUBMED | CROSSREF

3. Toledano M, Osorio R, Osorio E, Fuentes V, Prati C, Garcì-Godoy F. Sorption and solubility of resinbased restorative dental materials. J Dent 2003;31:43-50. PUBMED | CROSSREF

4. Mazzoni A, Tjäderhane L, Checchi V, Di Lenarda R, Salo T, Tay FR, Pashley DH, Breschi L. Role of dentin MMPs in caries progression and bond stability. J Dent Res 2015;94:241-251. PUBMED | CROSSREF

5. Osorio R, Yamauti M, Osorio E, Ruiz-Requena ME, Pashley D, Tay F, Toledano M. Effect of dentin etching and chlorhexidine application on metalloproteinase-mediated collagen degradation. Eur J Oral Sci 2011;119:79-85. PUBMED | CROSSREF

6. Zhang SC, Kern M. The role of host-derived dentinal matrix metalloproteinases in reducing dentin bonding of resin adhesives. Int J Oral Sci 2009;1:163-176. PUBMED | CROSSREF

7. Favetti M, Schroeder T, Montagner AF, Correa MB, Pereira-Cenci T, Cenci MS. Effectiveness of pretreatment with chlorhexidine in restoration retention: a 36-month follow-up randomized clinical trial. J Dent 2017;60:44-49. PUBMED | CROSSREF

8. Niu LN, Zhang W, Pashley DH, Breschi L, Mao J, Chen JH, Tay FR. Biomimetic remineralization of dentin Dent Mater 2014;30:77-96. PUBMED | CROSSREF

9. Almahdy A, Koller G, Sauro S, Bartsch JW, Sherriff M, Watson TF, Banerjee A. Effects of MMP inhibitors incorporated within dental adhesives. J Dent Res 2012;91:605-611. PUBMED | CROSSREF

10. Epasinghe DJ, Yiu CK, Burrow MF, Hiraishi N, Tay FR. The inhibitory effect of proanthocyanidin on soluble and collagen-bound proteases. J Dent 2013;41:832-839. PUBMED | CROSSREF

11. Santerre JP, Shajii L, Leung BW. Relation of dental composite formulations to their degradation and the release of hydrolyzed polymeric-resin-derived products. Crit Rev Oral Biol Med 2001;12:136-151. PUBMED | CROSSREF

12. Lehmann N, Debret R, Roméas A, Magloire H, Degrange M, Bleicher F, Sommer P, Seux D. Self-etching increases matrix metalloproteinase expression in the dentin-pulp complex. J Dent Res 2009;88:77-82. PUBMED | CROSSREF

13. Perumal S, Antipova O, Orgel JP. Collagen fibril architecture, domain organization, and triple-helical conformation govern its proteolysis. Proc Natl Acad Sci U S A 2008;105:2824-2829. PUBMED | CROSSREF

14. Fields GB. Interstitial collagen catabolism. J Biol Chem 2013;288:8785-8793. PUBMED | CROSSREF

15. Bertassoni LE. Dentin on the nanoscale: hierarchical organization, mechanical behavior and bioinspired engineering. Dent Mater 2017;33:637-649. PUBMED | CROSSREF

16. Bertassoni LE, Orgel JP, Antipova O, Swain MV. The dentin organic matrix - limitations of restorative dentistry hidden on the nanometer scale. Acta Biomater 2012;8:2419-2433. PUBMED | CROSSREF

17. Bertassoni LE, Swain MV. Removal of dentin non-collagenous structures results in the unraveling of microfibril bundles in collagen type I. Connect Tissue Res 2017;58:414-423. PUBMED | CROSSREF

18. Scheffel DL, Hebling J, Scheffel RH, Agee K, Turco G, de Souza Costa CA, Pashley D. Inactivation of matrixbound matrix metalloproteinases by cross-linking agents in acid-etched dentin. Oper Dent 2014;39:152-158. PUBMED | CROSSREF

19. Toledano M, Aguilera FS, Yamauti M, Ruiz-Requena ME, Osorio R. In vitro load-induced dentin collagenstabilization against MMPs degradation. J Mech Behav Biomed Mater 2013;27:10-18. PUBMED | CROSSREF

20. Mazzoni A, Scaffa P, Carrilho M, Tjäderhane L, Di Lenarda R, Polimeni A, Tezvergil-Mutluay A, Tay FR, Pashley DH, Breschi L. Effects of etch-and-rinse and self-etch adhesives on dentin MMP-2 and MMP-9. J Dent Res 2013;92:82-86.

PUBMED | CROSSREF 
21. Pessoa JI, Guimarães GN, Viola NV, da Silva WJ, de Souza AP, Tjäderhane L, Line SR, Marques MR. In situ study of the gelatinase activity in demineralized dentin from rat molar teeth. Acta Histochem 2013;115:245-251. PUBMED | CROSSREF

22. Hannas AR, Pereira JC, Granjeiro JM, Tjäderhane L. The role of matrix metalloproteinases in the oral environment. Acta Odontol Scand 2007;65:1-13. PUBMED | CROSSREF

23. Krizkova A, Zitka O, Adam V, Kizek R, Masarik M, Stiborova M, Eckschager T, Chavis GJ. Assays for determination of matrix metalloproteinases and their activity. Trends Analyt Chem 2011;30:1819-1832. CROSSREF

24. Cieplak P, Strongin AY. Matrix metalloproteinases - From the cleavage data to the prediction tools and beyond. Biochim Biophys Acta Mol Cell Res 2017;1864:1952-1963.

PUBMED | CROSSREF

25. Jacobsen JA, Major Jourden JL, Miller MT, Cohen SM. To bind zinc or not to bind zinc: an examination of innovative approaches to improved metalloproteinase inhibition. Biochim Biophys Acta 2010;1803:72-94. PUBMED | CROSSREF

26. Xu X, Chen Z, Wang Y, Bonewald L, Steffensen B. Inhibition of MMP-2 gelatinolysis by targeting exodomain-substrate interactions. Biochem J 2007;406:147-155. PUBMED | CROSSREF

27. Page-McCaw A, Ewald AJ, Werb Z. Matrix metalloproteinases and the regulation of tissue remodelling. Nat Rev Mol Cell Biol 2007;8:221-233. PUBMED | CROSSREF

28. Mazzoni A, Breschi L, Carrilho M, Nascimento FD, Orsini G, Ruggeri A Jr, Gobbi P, Manzoli L, Tay FR, Pashley DH, Tjäderhane L. A review of the nature, role, and function of dentin non-collagenous proteins. Part II: enzymes, serum proteins, and growth factors. Endod Topics 2009;21:19-40. CROSSREF

29. Bedran-Russo AK, Pauli GF, Chen SN, McAlpine J, Castellan CS, Phansalkar RS, Aguiar TR, Vidal CM, Napotilano JG, Nam JW, Leme AA. Dentin biomodification: strategies, renewable resources and clinical applications. Dent Mater 2014;30:62-76. PUBMED | CROSSREF

30. Sabatini C, Pashley DH. Mechanisms regulating the degradation of dentin matrices by endogenous dentin proteases and their role in dental adhesion. A review. Am J Dent 2014;27:203-214. PUBMED

31. Scheffel DL, Hebling J, Scheffel RH, Agee KA, Cadenaro M, Turco G, Breschi L, Mazzoni A, de Souza Costa CA, Pashley DH. Stabilization of dentin matrix after cross-linking treatments, in vitro. Dent Mater 2014;30:227-233. PUBMED | CROSSREF

32. Tezvergil-Mutluay A, Agee KA, Hoshika T, Carrilho M, Breschi L, Tjäderhane L, Nishitani Y, Carvalho RM, Looney S, Tay FR, Pashley DH. The requirement of zinc and calcium ions for functional MMP activity in demineralized dentin matrices. Dent Mater 2010;26:1059-1067. PUBMED | CROSSREF

33. Mei ML, Li QL, Chu CH, Yiu CK, Lo EC. The inhibitory effects of silver diamine fluoride at different concentrations on matrix metalloproteinases. Dent Mater 2012;28:903-908. PUBMED | CROSSREF

34. Tezvergil-Mutluay A, Mutluay M, Seseogullari-Dirihan R, Agee KA, Key WO, Scheffel DL, Breschi L, Mazzoni A, Tjäderhane L, Nishitani Y, Tay FR, Pashley DH. Effect of phosphoric acid on the degradation of human dentin matrix. J Dent Res 2013;92:87-91. PUBMED | CROSSREF

35. Seseogullari-Dirihan R, Mutluay MM, Pashley DH, Tezvergil-Mutluay A. Is the inactivation of dentin proteases by crosslinkers reversible? Dent Mater 2017;33:e62-e68. PUBMED | CROSSREF

36. Fields GB. New strategies for targeting matrix metalloproteinases. Matrix Biol 2015;44-46:239-246. PUBMED | CROSSREF

37. Breschi L, Mazzoni A, Ruggeri A, Cadenaro M, Di Lenarda R, De Stefano Dorigo E. Dental adhesion review: aging and stability of the bonded interface. Dent Mater 2008;24:90-101. PUBMED | CROSSREF

38. Hass V, de Paula AM, Parreiras S, Gutiérrez MF, Luque-Martinez I, de Paris Matos T, Bandeca MC, Loguercio AD, Yao X, Wang Y, Reis A. Degradation of dentin-bonded interfaces treated with collagen cross-linking agents in a cariogenic oral environment: an in situ study. J Dent 2016;49:60-67. PUBMED | CROSSREF 
39. Neri JR, Yamauti M, da Silveira FD, Mendonça JS, de Carvalho RM, Santiago SL. Influence of dentin biomodification with epigallocatechin-3-gallate on the bond strength of self-etch adhesive: twelve-month results. Int J Adhes Adhes 2016;71:81-86. CROSSREF

40. El Gezawi M, Haridy R, Abo Elazm E, Al-Harbi F, Zouch M, Kaisarly D. Microtensile bond strength, 4-point bending and nanoleakage of resin-dentin interfaces: effects of two matrix metalloproteinase inhibitors. J Mech Behav Biomed Mater 2018;78:206-213. PUBMED | CROSSREF

41. Siqueira FS, Hilgemberg B, Araujo LC, Hass V, Bandeca MC, Reis A, Gomes JC, Cardenas AF, Loguercio AD. Effect of phosphoric acid containing MMP-inactivator on the properties of resin bonding to eroded dentin. J Adhes Dent 2019;21:149-158. PUBMED

42. Comba A, Maravic T, Valente L, Girlando M, Cunha SR, Checchi V, Salgarello S, Tay FR, Scotti N, Breschi L, Mazzoni A. Effect of benzalkonium chloride on dentin bond strength and endogenous enzymatic activity. J Dent 2019;85:25-32. PUBMED | CROSSREF

43. de Menezes LR, da Silva EO, Maurat da Rocha LV, Ferreira Barbosa I, Rodrigues Tavares M. The use of clays for chlorhexidine controlled release as a new perspective for longer durability of dentin adhesion. J Mater Sci Mater Med 2019;30:132. PUBMED | CROSSREF

44. Simmer FS, da Silva EM, Bezerra RD, Miranda ME, Noronha Filho JD, Amaral CM. Bond stability of conventional adhesive system with MMP inhibitors to superficial and deep dentin. J Mech Behav Biomed Mater 2019;100:103402 PUBMED | CROSSREF

45. Islam SM, Hiraishi N, Nassar M, Sono R, Otsuki M, Takatsura T, Yiu C, Tagami J. In vitro effect of hesperidin on root dentin collagen and de/re-mineralization. Dent Mater J 2012;31:362-367. PUBMED | CROSSREF

46. Porto IC, Nascimento TG, Oliveira JM, Freitas PH, Haimeur A, França R. Use of polyphenols as a strategy to prevent bond degradation in the dentin-resin interface. Eur J Oral Sci 2018;126:146-158. PUBMED | CROSSREF

47. Huang B, Cvitkovitch DG, Santerre JP, Finer Y. Biodegradation of resin-dentin interfaces is dependent on the restorative material, mode of adhesion, esterase or MMP inhibition. Dent Mater 2018;34:1253-1262. PUBMED | CROSSREF

48. Brackett MG, Li N, Brackett WW, Sword RJ, Qi YP, Niu LN, Pucci CR, Dib A, Pashley DH, Tay FR. The critical barrier to progress in dentine bonding with the etch-and-rinse technique. J Dent 2011;39:238-248. PUBMED | CROSSREF

49. Montagner AF, Sarkis-Onofre R, Pereira-Cenci T, Cenci MS. MMP inhibitors on dentin stability: a systematic review and meta-analysis. J Dent Res 2014;93:733-743. PUBMED | CROSSREF

50. Tjäderhane L, Nascimento FD, Breschi L, Mazzoni A, Tersariol IL, Geraldeli S, Tezvergil-Mutluay A, Carrilho MR, Carvalho RM, Tay FR, Pashley DH. Optimizing dentin bond durability: control of collagen degradation by matrix metalloproteinases and cysteine cathepsins. Dent Mater 2013;29:116-135. PUBMED | CROSSREF

51. Moon PC, Weaver J, Brooks CN. Review of matrix metalloproteinases' effect on the hybrid dentin bond layer stability and chlorhexidine clinical use to prevent bond failure. Open Dent J 2010;4:147-152. PUBMED | CROSSREF

52. Breschi L, Martin P, Mazzoni A, Nato F, Carrilho M, Tjäderhane L, Visintini E, Cadenaro M, Tay FR, De Stefano Dorigo E, Pashley DH. Use of a specific MMP-inhibitor (galardin) for preservation of hybrid layer. Dent Mater 2010;26:571-578. PUBMED | CROSSREF

53. Hiraishi N, Sono R, Sofiqul I, Yiu C, Nakamura H, Otsuki M, Takatsuka T, Tagami J. In vitro evaluation of plant-derived agents to preserve dentin collagen. Dent Mater 2013;29:1048-1054. PUBMED | CROSSREF

54. Fawzy AS, Nitisusanta LI, Iqbal K, Daood U, Neo J. Riboflavin as a dentin crosslinking agent: ultraviolet A versus blue light. Dent Mater 2012;28:1284-1291. PUBMED | CROSSREF

55. Li J, Chen B, Hong N, Wu S, Li Y. Effect of baicalein on matrix metalloproteinases and durability of resindentin bonding. Oper Dent 2018;43:426-436. PUBMED | CROSSREF 
56. Osorio R, Yamauti M, Osorio E, Román JS, Toledano M. Zinc-doped dentin adhesive for collagen protection at the hybrid layer. Eur J Oral Sci 2011;119:401-410. PUBMED | CROSSREF

57. Almahdy A, Koller G, Festy F, Bartsch JW, Watson TF, Banerjee A. An MMP-inhibitor modified adhesive primer enhances bond durability to carious dentin. Dent Mater 2015;31:594-602. PUBMED | CROSSREF

58. da Silva EM, de Sá Rodrigues CU, de Oliveira Matos MP, de Carvalho TR, dos Santos GB, Amaral CM. Experimental etch-and-rinse adhesive systems containing MMP-inhibitors: physicochemical characterization and resin-dentin bonding stability. J Dent 2015;43:1491-1497. PUBMED | CROSSREF

59. Lenzi T, Tedesco TK, Soares FZ, Loguercio AD, Rocha RO. Chlorhexidine application for bond strength preservation in artificially-created caries-affected primary dentin. Int J Adhes Adhes 2014;54:51-56. CROSSREF

60. Carrilho MR, Tay FR, Donnelly AM, Agee KA, Tjäderhane L, Mazzoni A, Breschi L, Foulger S, Pashley DH. Host-derived loss of dentin matrix stiffness associated with solubilization of collagen. J Biomed Mater Res B Appl Biomater 2009;90:373-380. PUBMED | CROSSREF

61. Blackburn RS, Harvey A, Kettle LL, Manian AP, Payne JD, Russell SJ. Sorption of chlorhexidine on cellulose: mechanism of binding and molecular recognition. J Phys Chem B 2007;111:8775-8784. PUBMED | CROSSREF

62. Stanislawczuk R, Pereira F, Muñoz MA, Luque I, Farago PV, Reis A, Loguercio AD. Effects of chlorhexidine-containing adhesives on the durability of resin-dentine interfaces. J Dent 2014;42:39-47. PUBMED | CROSSREF

63. Priyadarshini BM, Selvan ST, Lu TB, Xie H, Neo J, Fawzy AS. Chlorhexidine nanocapsule drug delivery approach to the resin-dentin interface. J Dent Res 2016;95:1065-1072. PUBMED | CROSSREF

64. Ricci HA, Sanabe ME, de Souza Costa CA, Pashley DH, Hebling J. Chlorhexidine increases the longevity of in vivo resin-dentin bonds. Eur J Oral Sci 2010;118:411-416. PUBMED | CROSSREF

65. Valério RA, Galo R, Galafassi D, Corona SA, Borsatto MC. Four-year clinical prospective follow-up of resin composite restoration after selective caries removal using Er:YAG laser. Clin Oral Investig 2019 Nov 4. doi: 10.1007/s00784-019-03082-w. [Epub ahead of print] PUBMED | CROSSREF

66. Galafassi D, Scatena C, Galo R, Curylofo-Zotti FA, Corona SA, Borsatto MC. Clinical evaluation of composite restorations in Er:YAG laser-prepared cavities re-wetting with chlorhexidine. Clin Oral Investig 2017;21:1231-1241. PUBMED | CROSSREF

67. Araújo MS, Souza LC, Apolonio FM, Barros LO, Reis A, Loguercio AD, Saboia VP. Two-year clinical evaluation of chlorhexidine incorporation in two-step self-etch adhesive. J Dent 2015;43:140-148. PUBMED | CROSSREF

68. Sartori N, Stolf SC, Silva SB, Lopes GC, Carrilho M. Influence of chlorhexidine digluconate on the clinical performance of adhesive restorations: a 3-year follow-up. J Dent 2013;41:1188-1195. PUBMED | CROSSREF

69. Tu G, Xu W, Huang H, Li S. Progress in the development of matrix metalloproteinase inhibitors. Curr Med Chem 2008;15:1388-1395. PUBMED | CROSSREF

70. Imbery TA, Kennedy M, Janus C, Moon PC. Evaluating EDTA as a substitute for phosphoric acid-etching of enamel and dentin. Gen Dent 2012;60:e55-e61. PUBMED

71. Tezvergil-Mutluay A, Agee KA, Uchiyama T, Imazato S, Mutluay MM, Cadenaro M, Breschi L, Nishitan Y, Tay FR, Pashley DH. The inhibitory effects of quaternary ammonium methacrylates on soluble and matrix-bound MMPs. J Dent Res 2011;90:535-540. PUBMED | CROSSREF

72. Sabatini C, Kim JH, Ortiz Alias P. In vitro evaluation of benzalkonium chloride in the preservation of adhesive interfaces. Oper Dent 2014;39:283-290. PUBMED | CROSSREF

73. Daood U, Yiu CK, Burrow MF, Niu LN, Tay FR. Effect of a novel quaternary ammonium silane on dentin protease activities. J Dent 2017;58:19-27. PUBMED | CROSSREF 
74. Daood D, Yiu CK, Burrow MF, Niu LN, Tay FR. Effect of a novel quaternary ammonium silane cavity disinfectant on durability of resin-dentine bond. J Dent 2017;60:77-86. PUBMED | CROSSREF

75. Tezvergil-Mutluay A, Agee KA, Hoshika T, Uchiyama T, Tjäderhane L, Breschi L, Mazzoni A, Thompson JM, McCracken CE, Looney SW, Tay FR, Pashley DH. Inhibition of MMPs by alcohols. Dent Mater 2011;27:926-933. PUBMED | CROSSREF

76. Kuhn E, Farhat P, Teitelbaum AP, Mena-Serrano A, Loguercio AD, Reis A, Pashley DH. Ethanol-wet bonding technique: clinical versus laboratory findings. Dent Mater 2015;31:1030-1037. PUBMED | CROSSREF

77. Liu Y, Chen M, Yao X, Xu C, Zhang Y, Wang Y. Enhancement in dentin collagen's biological stability after proanthocyanidins treatment in clinically relevant time periods. Dent Mater 2013;29:485-492. PUBMED | CROSSREF

78. Cilli R, Prakki A, de Araújo PA, Pereira JC. Influence of glutaraldehyde priming on bond strength of an experimental adhesive system applied to wet and dry dentine. J Dent 2009;37:212-218. PUBMED | CROSSREF

79. Chiang YS, Chen YL, Chuang SF, Wu CM, Wei PJ, Han CF, Lin JC, Chang HT. Riboflavin-ultraviolet-Ainduced collagen cross-linking treatments in improving dentin bonding. Dent Mater 2013;29:682-692. PUBMED | CROSSREF

80. Epasinghe D, Yiu C, Burrow M. Effect of proanthocyanidin incorporation into dental adhesive on durability of resin-dentin bond. Int J Adhes Adhes 2015;63:145-151. CROSSREF

81. Bedran-Russo AK, Pashley DH, Agee K, Drummond JL, Miescke KJ. Changes in stiffness of demineralized dentin following application of collagen crosslinkers. J Biomed Mater Res B Appl Biomater 2008;86B:330-334. PUBMED | CROSSREF

82. Osorio R, Yamauti M, Osorio E, Ruiz-Requena ME, Pashley DH, Tay FR, Toledano M. Zinc reduces collagen degradation in demineralized human dentin explants. J Dent 2011;39:148-153. PUBMED | CROSSREF

83. Osorio R, Osorio E, Medina-Castillo AL, Toledano M. Polymer nanocarriers for dentin adhesion. J Dent Res 2014;93:1258-1263. PUBMED | CROSSREF

84. Santamaria S, Nuti E, Cercignani G, La Regina G, Silvestri R, Supuran CT, Rossello A. Kinetic characterization of 4,4'-biphenylsulfonamides as selective non-zinc binding MMP inhibitors. J Enzyme Inhib Med Chem 2015;30:947-954. PUBMED | CROSSREF

85. Tezvergil-Mutluay A, Mutluay MM, Agee KA, Seseogullari-Dirihan R, Hoshika T, Cadenaro M, Breschi L, Vallittu P, Tay FR, Pashley DH. Carbodiimide cross-linking inactivates soluble and matrix-bound MMPs, in vitro. J Dent Res 2012;91:192-196. PUBMED | CROSSREF

86. Singh P, Nagpal R, Singh UP. Effect of dentin biomodifiers on the immediate and long-term bond strengths of a simplified etch and rinse adhesive to dentin. Restor Dent Endod 2017;42:188-199. PUBMED | CROSSREF

87. Castellan CS, Pereira PN, Grande RH, Bedran-Russo AK. Mechanical characterization of proanthocyanidin-dentin matrix interaction. Dent Mater 2010;26:968-973. PUBMED | CROSSREF

88. Chuang CH, Yeh CL, Yeh SL, Lin ES, Wang LY, Wang YH. Quercetin metabolites inhibit MMP-2 expression in A549 lung cancer cells by PPAR- $\gamma$ associated mechanisms. J Nutr Biochem 2016;33:45-53. PUBMED | CROSSREF

89. Gotti VB, Feitosa VP, Sauro S, Correr-Sobrinho L, Leal FB, Stansbury JW, Correr AB. Effect of antioxidants on the dentin interface bond stability of adhesives exposed to hydrolytic degradation. J Adhes Dent 2015;17:35-44. PUBMED

90. Monteiro TM, Basting RT, Turssi CP, França FG, Amaral FL. Influence of natural and synthetic metalloproteinase inhibitors on bonding durability of an etch-and-rinse adhesive to dentin. Int J Adhes Adhes 2013;47:83-88. CROSSREF

91. Liu Y, Tjäderhane L, Breschi L, Mazzoni A, Li N, Mao J, Pashley DH, Tay FR. Limitations in bonding to dentin and experimental strategies to prevent bond degradation. J Dent Res 2011;90:953-968. PUBMED | CROSSREF 
92. Fugolin AP, Dobson A, Mbiya W, Navarro O, Ferracane JL, Pfeifer CS. Use of (meth)acrylamides as alternative monomers in dental adhesive systems. Dent Mater 2019;35:686-696. PUBMED | CROSSREF

93. Fugolin AP, Dobson A, Ferracane JL, Pfeifer CS. Effect of residual solvent on performance of acrylamidecontaining dental materials. Dent Mater 2019;35:1378-1387.

PUBMED | CROSSREF

94. Tekçe N, Tuncer S, Demirci M, Balci S. Do matrix metalloproteinase inhibitors improve the bond durability of universal dental adhesives? Scanning 2016;38:535-544.

PUBMED | CROSSREF 